to the Cabinet-level committee proposed in the bill. And there is also the problem that the Administration would not take kindly to such a large spending commitment in such difficult financial times.

What are the chances that the bill will be passed? Staff members of the Senate Committee on Aeronautical and Space Sciences are hoping to get some hearings underway in February. But one problem is that the bill has also been referred to the Senate Commerce Committee whose chairman, Warren Magnuson, is the bill's chief sponsor. Unless some formula can be worked out for both committees to consider the legislation simultaneously, its passage through the mill will be slowed down. Moreover, even if the bill is passed by the Senate before Congress adjourns for the October Congressional elections, there is no sign of interest in the House of Representatives. The House Science and Astronautics Committee, for example, has its plate full with energy matters, and would be unlikely to take up the bill in time to get it passed by the House this year.

Nevertheless, the bill is likely to spark considerable discussion in the scientific community, just as Kennedy's bill did two years ago.

\section{No astronomical ghosts laid}

\section{Edward Phillips}

Dr David Evans, the Welsh-born optical astronomer, sees himself as the enfant terrible of British astronomy, although some would say vieux terrible.
After many years in British and South African astronomy he now works at the University of Texas, but last week he was in London and at the monthly meeting of the Royal Astronomical Society. And for once the society forsook its normal academic fare to allow Dr Evans to present his views on the management of British optical astronomy.

Dr Evans seemed to be attributing what he called "the depressed state of British optical astronomy" to two factors. First, he blamed "overbureaucratisation" which he said resulted in the voice of optical astronomy emanating from administrators instead of from the scientists working at the observatories. And, second, he recognised "an unfortunate relationship between optical and theoretical astronomers", there being a tendency to disparage any work which originates too far from what he termed the Cambridge-Caltech axis.

All this was greatly enjoyed by the younger astronomers present, while their elders were notably less amused. But after this cracking start Dr Evans lapsed into a panegyric for astronomy at the University of Texas, in particular the McDonald observatory at Fort Davis which he put forward as the ideal site for the proposed Northern Hemisphere Observatory.

In the circumstances the president of the society, Professor D. E. Blackwell, was probably being benevolent in ruling that there was insufficient time for discussion, although Sir Bernard Lovell was allowed to say a few words in support of British optical astronomy.

Unfortunately, though, this meeting, which could have served as a much needed exorcism after all the troubles that have beset British optical astron- omy, fell far short of achieving any useful purpose. The Royal Astronomical Society is, however, planning a meeting where officials of the Science Research Council will be able to explain the latest policies in astronomy. Maybe this will be the occasion for casting out a few devils.

\section{Keeping a non-stop world}

Having sacked the Earth to the point where (arguably) we are virtually bankrupt of fossil fuels, it is good to see a politician draw the line at actually stopping the planet from spinning in the pursuit of new energy sources.

In a House of Commons debate on tidal power British Member of Parliament $\mathrm{Mr}$ Tam Dalyell asked whether or not the government was prepared to talk about tidal energy at an international level since, he observed, there is a serious question of reduced Earth spin if several countries embarked on such schemes. Mr Dalyell also asked whether or not there would be adverse effects on the ocean bed and whether such fears need be harboured if there were a twobasin estuary scheme.

His point in raising these questions, apparently, was to demonstrate that people who proposed tidal energy schemes were aware of the attendant anxieties and, he submitted, it would be silly not to express a certain sensitivity towards them. Which of course is true, though, it must be added, it would not be ever so silly since the estimated time required for tidal harness schemes to stop the Earth's spin is something in the region of 10 million years.

\title{
correspondence
}

\section{Energy}

Sir-The United States is feeling the energy pinch and is beginning to realise that pertoleum, along with other critical materials, cannot last forever. This is causing us to intensify our efforts toward alternate energy sources and to examine how we can reduce consumption and increase reclamation. It is also causing critics, both locally and abroad, to accuse America of the 'mindless' utilisation of energy (Nature, 246, 116; 1973). Statistics are quoted about our small population using a third of the world's energy and implying that this energy is mostly wasted or used for personal comfort and enjoyment.
I will concede that we have wasted resources, most recently in Vietnam, and that we drive too much, have too much throw-away packaging, and more air conditioning than we really need. But I argue that the majority of the energy has been used productively. America has exported energy to the four corners of the world in the form of wheat, rice, soy beans, cotton, lumber, machine tools, tractors, airplanes, locomotives, and medicine.

We have exported American know how, fed and clothed both allies and enemies after World Wars I and II, and rebuilt their factories. Their factories today are more modern than our own. For much of this we have received little or no payment-yet these activities have caused depletion of our soil, natural resources, and treasury. I wish our critics in England, France, Russia, Germany, Japan, China, and the Middle East would remember some of these things when preparing their editorials.

In some instances we may have been guilty of exploitation and of not minding our own business. But, when it comes to energy, perhaps we have not used more than our fair share, considering the billions of BTU's used to make or grow the products we have given away. Yours faithfully, E. A. Aas

1235 De Paul Way,

Livermore,

California 94550 